\title{
The impacts of gender education on female entreprenuership: Breaking the glass ceilings for a prosperous new Nigeria
}

\section{Grace A.-T. Scent ${ }^{1}$, Christian Chima Chukwu ${ }^{2}$ and Obuzor Mezewo Emerinwe ${ }^{3}$}

\author{
${ }^{1}$ Niger Delta University. Department of Sociology and Anthropology. Wilberforce \\ Island. Nigeria. \\ ${ }^{2}$ Novena University. Department of Sociology. Ogume. Delta State. Nigeria. \\ Email: chukwuchidr@gmail.com. \\ ${ }^{3}$ Rivers State University. Faculty of Social Sciences. Department of Sociology. \\ Nkpolu. Oronworukwo. Port Harcourt. Nigeria.
}

\begin{abstract}
Gender education and entrepreneurship have become worldwide phenomena for women, particularly in patriarchy societies where all kinds of discriminations, subjugation against them are frightening realities of contemporary times. As a result, female entrepreneurship has been weighed down by poor education, social norms, and lack of access to free credit facilities. It is in this context that this paper examines the impacts of gender education on female entrepreneurship in Enugu urban, Enugu state, Nigeria. A survey design was employed and 300 respondents were selected using the simple random sampling technique. Out of this number of respondents, only $280(90.33 \%)$ structured questionnaire were returned and analyzed using both quantitative and qualitative methods. The distribution of the respondents showed 210 (75\%) were female entrepreneurs, while 70 respondents (25\%) were male entrepreneurs. Among the findings, an overwhelming majority of the respondents are of the view that the female entrepreneurs are important for the socio-economic transformation of the Enugu State, and by extension, Nigeria. Secondly, the study agrees that there is hardly a society where gender stereotypes do not exist but that these aspects of the gender belief system which are anti- female entrepreneurs' development have been over taken by the power of gender education. In addition, the study shows that gender education is the most viable and veritable vehicle for guaranteeing and sustaining female entrepreneurs to continue to expand entrepreneurship in Nigeria. Thirdly, this study has presented a different picture of women making some tremendous efforts in spite of all odds cannot be underestimated because their contributions have been remarkable despite the challenges they face in their quest to transform the patriarchal Igbo society, especially Enugu State. Based on this, the study concludes that the contributions of female entrepreneurs in Nigeria's entrepreneurship development cannot be underestimated
\end{abstract}

Received

Sept. 10, 2019

Accepted

Feb. 27, 2020

Release

Apr. 30, 2020

Open access

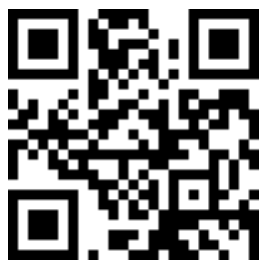

ORCID

(ㄱ) 0000-0001-8846-6881 Grace A.-T. Scent

(D) 0000-0002-4290-234X Christian Chima Chukwu

D 0000-0001-7836-3977

Obuzor Mezewo

Emerinwe 
because their contributions have been remarkable despite the challenges they face. In this vein, the study suggests that gender education should be a priority to halt all forms of discriminatory practices against female entrepreneurs and in the same vein, calls for elimination of prejudices and customary practices that are based on the idea of the inferiority or superiority of either sex or on stereotyped roles for men and women. Above all, government should, through financial institutions, grant free interest loans to encourage female entrepreneurs plunge themselves into businesses to sustain the breaking of the glass ceilings.

Keywords: Gender; Education; Women entrepreneurship; Female entrepreneurship; Employment creation.

\section{Introduction}

In the present day society, particularly when the issue of economic development is discussed, emphasis seems to be centered on the ever-increasing demand for the best quality of personnel to manage entrepreneurship, independent of their gender. By implication, the process of economic emancipation, subjugation and discrimination propelled by patriarchy becomes a necessity for economic development of any patriarchal infested society such as Nigeria. Admittedly, the place of women in entrepreneurial activity is abysmally poor as it cannot be equated to any statistical figure despite the fact that women entrepreneurs have an important contribution to employment creation and economic growth and contribute to the diversity of entrepreneurship. Substantiating, the European Commission (2002) in its report on Good practices in the promotion of female entrepreneurship, argued that women face a number of gender-specific barriers to starting up and running a business that have to be tackled as women are considered "a latent source of economic growth and new jobs and should be encouraged". Therefore, the core argument to this day for pushing women's entrepreneurship into the heart of emerging scholars to explore is highlighted by Ahl (2002) when he argues that female entrepreneurs are an "engine of economic growth". Sequel to this, the basis for this introductory part of this study is the acknowledgement that female entrepreneurship is important for economic performance despite the overwhelming influence of patriarchy targeted at making it neither here nor there.

Throughout history, human beings have been innovative and resourceful in their efforts to transform the society for meaningful development. Since the loss of the Garden of Eden, man's quest to build another new dreamland has stretched him into developing his entrepreneurial skills for the purposes of improving himself and altering his immediate milieu into a paragon of beauty. In other words, by taking advantage of business opportunities and initiating sustainable action to ensure success, man's ingenuity has been identified as a means to constructing a new heaven. For example, men had, for many years, dreamed of a new power generation which would be more useful than the work animals, windmills, or water wheels, but no one did anything until James Watt invented the power of steam to spin and weave cotton and wool, and by implication, accomplishing many important tasks for man's comfort. Thereafter, there was the invention of the steamboat by Robert Fulton and the invention of the locomotive by George Stephenson, including invention of the electric engine and electric locomotive and of course, Michael Faraday's invention of electricity. All these emanated from the multiplier effects of the entrepreneurship skills of James Watt. Schumpeter (1934) recognizes this innate ability in man as 'a progression of change where innovation is the 
most very important function of the entrepreneur. It is in this context that scholars generally agree that each of the entrepreneurship skills of man has added to the comforts and joys of the humanity as each of the innovative creations has birthed new industries which have offered employments to many men and women thereby making their lives meaningful. By this, it is evident that entrepreneurship enhances the well being of humankind through its activities which solely rest on man identifying and properly harnessing his ingenuity to achieving the goal of self actualization.

Since development entails a qualitative change and improvement in the lives of people, excluding, discriminating or marginalizing women in whatever form is counter development. It is in concord with this assertion that article 2 of the convention on the elimination of all forms of discrimination against women (CEDAW) enjoins state parties to condemn discrimination against women in all forms. In the same vein, article 5 calls for elimination of prejudices and customary practices that are based on the idea of the inferiority or superiority of either sex or on stereotyped roles for men and women. This is in conformity with article 5.5.2 that emphasizes the need to eliminate those aspects of our culture that inhibit the development of positive of self-identity of women and their full participation in society. While it acknowledges the obnoxious role of patriarchy in section 5.4.1, it recommends in section 5.4.2 that structures that prop-up patriarchy should be discouraged through education, particularly gender education and enlightenment.

From the foregoing, entrepreneurship improves the living standards of a people through its numerous activities. Its significance cannot therefore be overemphasized, especially when viewed against the background that the Nigerian women, bound by social norms of various dimensions, particularly patriarchy, are fast emerging as contending participants in the Nigerian entrepreneurial world to rewrite their narratives today than ever. Interestingly, it is important to observe that with their appearance doting on different business enterprises, especially those that were deemed exclusively for men, female entrepreneurs have increasingly become indispensable in the socio-economic transformation agenda of Nigeria. Prior to this epoch, women were regarded as weaklings, delicate, impure and incapable of any meaningful progress. By implication, social norms regarding gender and gender roles were indeed decisive factors within the culture of female entrepreneurship. Regrettably, these attributes were used to determine what women could do because patriarchal attitudes pervade the entire Igbo society.

From the foregoing, it is clear that Nigeria is a highly patriarchal society where men dominate all spheres of women's lives to the extent that women have been discriminated, and subjugated and schemed out of development of their different communities. As in other male dominated societies, the social relations and activities of Nigerian women and men are governed by patriarchal systems of socialization and cultural practices which enabled the interests of men above those of women. While overt gender-based discrimination is much less perceivable today, researches still show that social norms have not only continued to halt socio-economic activities of female entrepreneurs to the collective detriment of the Nigerian society, but also gender equality such that women are still vulnerable to socio-cultural practices since the gender belief system perceive them as having lower propensities to engage in entrepreneurship than men (Moore, 1990). Fundamentally, female entrepreneurs are particularly vulnerable to social norms in terms of the ability to access the entrepreneurial world, since the gender belief system may perceive women as having lower propensities to engage in entrepreneurship than men.

Consequent upon this, Nigerian female entrepreneurs have refused to be dispirited by the practice of patriarchy. Sequel to this, female entrepreneurs in the likes of Folorunsho Alakija, Hajia Bola Shagaya, Stella Okoli, Bimbo Alase, Fifi Ejindu, Linda Ikeji, Tela Fela Durotoye, Uche Eze-Pedro, Betty Irabor, and many others, to mention, but a few have emerged to reject exclusion, discrimination and marginalization foisted on them 
unjustifiably. Similarly, with their outstanding emergence, the structures that prop-up patriarchy have been silenced in line with the realization of goals of gender education and enlightenment. While it remains a fact that Nigerian female entrepreneurs have made their impacts felt and accordingly, earned admiration around the world, especially when the ilk of Folorunsho Alakija, the richest black woman, recently tutored as being wealthier than Oprah Winifred, it is important to admit, from all indices, that female entrepreneurs, of which Folorunsho Alakija is part and parcel, have long ceased to be socialized, indoctrinated and coerced into cooperating with the patriarchal system.

Nevertheless, since the Nigerian society, like every other human society in the world, is androgynous i.e. bifurcated into male and female with same human personality and dignity from conception to birth, female entrepreneurs are prerequisites for the transformation of the Nigeria's economy, especially that of Enugu State. Based on this, the emergence of female entrepreneurs has rekindled the impacts of gender education through their creativity and dexterity. Thus, as agents of transformation, the dynamic roles and easy adaptation to changes of female entrepreneurs to engage in sustainable economic development through entrepreneurship is worthwhile. It is in this context that people who own and work in their own business, including unlimited enterprises and also have wage earners are called entrepreneurs (OECD, 2016). While it is of utmost concern $x-$ raying entrepreneurship in general, the issue of female entrepreneurs being behind their male counterparts in the possession of businesses and access to credit facilities is worrisome.

It is worthy to recognize that of the 17 sustainable development goals, and 169 targets, the first, and third emphasize the need to end poverty everywhere, and enhance well-being and healthy lives; the fourth, fifth and tenth goals, highlight amongst others, ensuring inclusive and equitable quality education and promote lifelong learning opportunities for all; achieving gender equality and empower all women and girls as well as promoting peaceful and providing guards against exclusion at different levels and recognizing the overlap between multiple forms of exclusion and marginalization. These goals are very fundamental to realizing the significance of gender education and female entrepreneurship in Nigeria. As observed earlier, inclusion refers to eliminating discriminatory laws and implementing social protection to enhance equality. This goes beyond social protection purely to prevent people, especially women from falling below the absolute poverty line.

From the foregoing, the raison d'être for deciding on women as a special group in this study, despite the social norms halting their full participation in entrepreneurship is to examine the impacts of gender education on female entrepreneurship with the view to breaking the glass ceilings for a prosperous new Nigeria.

\section{Statement of the problem}

The impacts of gender education on female entrepreneurship, particularly in patriarchal societies, of which Nigeria is one, is inconsequential because women are regarded as weaklings, delicate, and impure to be engaged in any serious enterprise. Unfortunately, these attributes were used to determine what women could do because patriarchal attitudes pervade the entire Igbo society. Clearly, male preference and the marginalization of women are the consequences of gender stereotyping which through socialization portray the female as inferior, and restrict what she does and the role she plays, while the male harbours no such inhibitions. Since women have been oppressed and commandeered to remain passive, inarticulate, and subservient and emasculated, the low level of education amongst women have not only subjugated them, but also aggravated the gender imbalance in the entrepreneurial world. As a result, they have become disillusioned for several decades. Besides, female entrepreneurships have been constrained by enormous challenges such as government regulations, little or no access to 
finance, lack of access to information technology, lack of access to control property, and family dependence. From all viewpoints, this has negatively affected women social mobility pattern, and led to the failure of many entrepreneurship managed by females. Thus, the exclusion, discrimination and marginalization of women from participating fully in entrepreneurship will continue to increase poverty leading to a situation Diane Pearce referred to as feminization of poverty.

The objective of this study is basically to examine the impacts of gender education on female entrepreneurship with a view to breaking the glass ceilings for new prosperous Nigerian society. In the course of the study, whether social norms could hinder women from improving their economic status would also be investigated. Finally, it also suggest panacea to challenges confronting female entrepreneurs in Nigeria, particularly in Enugu State.

The study is premised on two research questions formulated to guide the study. They include:

(a). Does gender education have any impact(s) on female entrepreneurs in Enugu state?

(b). Do social norms hinder female entrepreneurs from improving their economic status?

\section{Methodology}

The population of the study comprised all entrepreneurs selected from Enugu Urban in Enugu State for this study. A survey design was employed and 300 respondents were selected using the simple random sampling technique. Out of this, only $280(90.33 \%)$ of them were analyzed. In essence, a total of 280 questionnaires were administered to respondents, and analyzed using the descriptive statistics and presented in percentages. In analyzing, both quantitative (structured questionnaire) and qualitative methods were employed to gather primary data from the respondents, while secondary data were obtained from books, journals, and the Internet. The structured questionnaire consisted of 12 questions, divided into 2 sections. Section A had three questions that focused mainly on the gender, age, and educational qualification of the respondents. These variables are relevant to the study because the study is basically targeted at women entrepreneurs in Enugu urban. The other 8 questions examined respondents' perception of gender education, and its importance on female entrepreneurs. The results of the qualitative study were tested with the quantitative study, which helped to strengthen the overall findings and conclusions of the study. The choice of women in this study was hinged on the fact that they are the main subject matter of the examination.

\section{Theoretical framework}

The Socialist Feminist theory which focuses on the public and private spheres of a woman's life is adopted for this study. It argues that liberation from discrimination, domination and exclusion can only be achieved by working to end both the economic and cultural sources of oppression (Eisenstein, 1999). Ehrenrcich (1976) used the term 'Capitalist patriarchy' to emphasize the existing mutual inter-dependence of the capitalist class structure and male dominance. The theory emphasizes that all members of the society are important stakeholders in changing the unfavourable situation and negative gender culture in the society. The theory also advocates that all-inclusive re-socialization and re-orientation of the entire society to change the negative capitalist patriarchal system which hinders female entrepreneurship is urgently needed. Since patriarchy denotes the rule of the father, or more generally the rule of men, the disadvantage and oppression of 
women are explained in terms of patriarchy - male dominance and oppression that demean; diminish and exclude women.

The rationale behind this theory is that women are oppressed as women because of social norms which discriminate and exclude them from improving themselves. The solution, therefore, is to integrate them into activities which will assist them regain their lost confidence and self esteem after being disillusioned for several decades. This position is in agreement with the concept of 'Women in Development (WID), which was initiated by women development experts, many working in the UN and other multilateral and bilateral agencies during the time of the Women's Decade of the UN (1975-1985).In their view, women's oppression was grounded on their economic position since they were relegated to inferior and dependent positions as housewives. Therefore, the solution is to get women into entrepreneurship so that they can earn money and become independent of men, the proponents of patriarchy and in the process, excel in their mission to be successful entrepreneurs and also advance their cause in any other human endeavour.

The core point of this theory rests on gender mainstreaming which encompasses all deliberate organizational strategies to bring a gender perspective into all aspects .of an institution's policy and activities, through building gender capacity and accountability. It is within this framework that the National Gender Policy was built to ensure gender parity and human dignity (Ejumodo, 2013). The Nigerian National Gender Policy was adopted officially in 2006 with the goal of eradicating poverty, achieving gender equality and inclusiveness in governance and development. Thus, by advocating the application of the 50-50 affirmative quota of the African Union, at all levels, the impacts of gender education on female entrepreneurship with the view to breaking the glass ceilings for a prosperous new Nigeria would be realizable.

\section{What is Entrepreneurship?}

In the attempt to explore the concept of female entrepreneurship which is central to this study, perhaps, it will be necessary to define and understand what entrepreneurship in its entirety means. In practical terms, entrepreneurship seems to connote ideas bothering on creating an extraordinary article, not necessarily to showcase man's creativity, and improves sustainable development but to chart a new course of being independent, taking risks without being running aground for the purposes of increasing his earnings for comfort. From creation, every individual is imbued with an innate endowment which when properly harnessed catapults him to his zenith. Ayogu and Agu (2015) views entrepreneurship as the ability to discern innovative business possibilities to benefit mankind, improves his immediate milieu and also charts new course of development. It is therefore in this circumstance that Sullivan and Meek (2012) argue that private enterprise has become a fundamental specialty amongst contemporary scholars to be explored. Concurring, GEM (2017) and Reynolds et al. (1999) agree that any endeavour at commencing a new business outfit that gives the owner self-employment, or assist him to expand an existing business unit could summarily be regarded as entrepreneurship. One could, from this perspective, contend that people who own and work in their own business, including unincorporated businesses and have wage earners are entrepreneurs (OECD 2016). Commenting on the influence of networking and strengthening entrepreneurship, the World Bank (2015) says in establishing networks with other entrepreneurs, identifying profitable business opportunities and accessing funding, as well as finding business partners, suppliers, employees and clients will sustain female entrepreneurs, but also enhance their skills.

Unmistakably, the capacity to form business relationships is very important to entrepreneurs as it allows them to establish contact with likeminded individuals. Obviously, research has shown that these business relationships enhance their ability to identify advantageous opportunities which would allow them to develop and grow their 
business ventures. Incontrovertibly, the Oxford Advanced Dictionary of Current English (Hornby, 1975) sees much sense in the ability to organize a business undertaking for a profitable yield, but not without tackling the risks therein. In a nutshell, entrepreneurship is the art and science of combining resources to produce new goods or services, suffices to say that entrepreneurship is all about change which we see as one of the major characteristics of an entrepreneur who as well search for change, responds to it and exploits it as an opportunity.

\section{Gender Education and female entrepreneurship in Nigeria}

Having taken a dive at understanding the concept of female entrepreneurship, the question that arises here from is: Can gender education be a path to the success of female entrepreneurship in Nigeria? Since it is argued that low education levels triggers a vicious cycle, wherein poorly educated women are left badly prepared to contribute to private enterprises, parents' motivation to invest in girls' schooling is unenthusiastic because of the failure to break even. However, with the projected population census figures of Nigeria being put at 190 million, the 2006 census which puts women at 74 million women has become a conservative estimate because the $61 \%$ of this population which is said to suffer from intellectual poverty has risen far more than this conventional projection. More worrisome is the absence of role models to mentor and motive women to embrace vocational gender education in order to equip them with the requirements to engage in entrepreneurship.

Nevertheless, since the essence of gender education in female entrepreneurship is increasing her knowledge and skills needed for her entry into the entrepreneurship, and also by raising her earnings, today's female entrepreneurs are poised, given the history of discrimination against them to benefit equally if not more than men. This is hinged on the fact that investing in gender education produces high social and economic returns and has long been recognized as a fundamental right with far-reaching impacts on human development and social progress (2014 National Bureau of Statistics). Generally speaking, the significance of education, whether gender or not, for the advancement of women was highlighted in the Beijing Platform for Action, which identified it as one of the 12 critical areas of concern that is central for gender equality and women empowerment. The Platform for Action also calls for the eliminating of discrimination in education on the basis of gender at all levels, eradicating illiteracy among women and improving access to vocational training, science and technology and continuing education.

With international exposures, especially conferences, workshops, and seminars organized by United Nations and other non-governmental organizations to improve the lots of women, scholars agree that education benefits women entrepreneurs by facilitating their participation into creating jobs and contributing substantially to the nation's economy. Concisely, gender education promotes women's entry into entrepreneurship by increasing their acquisition and possession of cognitive skills. Basically, the success of women's entry into entrepreneurship is wholly dependent on the possession of cognitive skills. By this, women are highly favoured going by the benefits of acquiring gender education coupled with its attendant economic returns. Thus, we can conclude that gender education is a pathway to reducing gender gaps in earnings and ensuring gender equality in Nigeria's entrepreneurship. Besides, since women are of immense significance, their huge impact in the sustenance of the Nigeria's economy cannot be ignored (Ayogu, Deborah \& Agu, Ogadimma, 2015). To this effect, women entrepreneurs are important and necessary for the economic development of Nigeria

From the foregoing, the recognition being accorded entrepreneurship, especially as it involves women is increasingly becoming a critical driver of economic growth, innovation (Niethammer, 2013) and poverty reduction (World Bank, 2015). As a crucial factor within the modern entrepreneurial culture, female entrepreneurship has helped to 
shape to a large extent the position entrepreneurship occupies in society and economic growth (OECD, 2012). Following this line of submission, it can be stated that the impact of gender education on female entrepreneurs, particularly as it concerns economic growth and sustainable development cannot be overemphasized. Any form of education that emphasizes the dignity of labour, encourages self - reliance and stimulates creativity is most required at this critical time for female entrepreneurship to bloom. Substantiating, education, according to Global Entrepreneurship Research Association (2017) holds that its economies are characterized by high levels of female entrepreneurial activity. Contributing to the discourse, Woetzel et al. (2015) assert that when women participate in the economy the same as men - as much as $\$ 28$ trillion, or 26 percent, to annual global GDP would be contributed by 2025. By implication, the speedy socio-economic transformation of a people is observed to depend on the competence of women who embraced education. This assertion is in agreement with the submission of Funmilola (2007) who avers that education bestows on women a disposition for a lifelong acquisition of knowledge, values, attitudes, competence and skills to excel in any human endeavour.

\section{Female entrepreneurship and economic development}

The concept of female entrepreneurship means many things to many people. Kaur, and Letic (2012) assert that it is essentially concerned with business organizations 'owned and managed by women' in its entirety. It could also mean the number of firms there are in which a woman holds more than 50 per cent ownership stakes (Jalilian, 2012). Another possible definition of female entrepreneurship focuses on the role women play in establishing business ventures as single founders or as co-founders, and their active engagement in the day-to-day management of businesses. For World Bank (2011), a woman entrepreneur is someone who 'has started a business alone or with other women, or is someone who is a principal in a family or partnership, or is shareholder and manager in a publicly held company. These two definitions summarize the introductory characteristics of the female entrepreneurial culture (Ugrinova, 2016). Female entrepreneurship in any given country comprises of two basic aspects: firstly, the rate at which women form start-ups, and, secondly, the number of businesses in the economy which are actively operated by women. While this classification provides a valuable guideline in distilling women entrepreneurs as a separate group within the general structure of entrepreneurship, it focuses, according to (Ugrinova, 2016), primarily on the ownership stakes women hold in companies and how they are engaged in managing them. As a result, the recognition being accorded entrepreneurship, especially as it involves women is increasingly becoming a critical driver of economic growth, innovation (Niethammer, 2013) and poverty reduction (World Bank, 2015). As a crucial factor within the modern entrepreneurial culture, female entrepreneurship has helped to shape to a large extent the position entrepreneurship occupies in society and economic growth (OECD, 2012).

\section{Social norms against female entrepreneurship}

Culture, according to Alfred Kroeber (1968) is a "the mass of learned and transmitted motor reactions, habits, techniques, ideas and values and the behaviour they induce" It could also be defined as the values, beliefs, behaviour, practices and material objects that constitute a people's way of life. The definition of culture is limitless. Be it as it may, it is generally agreed that it involves also the meaning and value of things, ideas, emotions and actions and is sometimes interpreted narrowly as custom or tradition (Mohammed and Adekeye, 2012; Otedetola and Ademola, 1986; Baden. 2000). It is also a toolbox that directs gender ideologies which often reinforce male power and the idea of women's inferiority. As a result, the dominance of patriarchal attitudes in the entire Igbo 
land has led to gender stereotyping. Such stereotyping is the reason for male preference and why fewer educational opportunities are given to women. Such social norms which support male superiority are culturally transmitted from one generation to another through the process of socialization (Witt, 1997; Bonvillain, 2006). Unfortunately, gender role differentiation through socialization always portrays the female as inferior, restricts what she does and the role she plays. Consequently, this has negatively affected her social mobility pattern (Omadjohwoefe, 2011).

From this angle, it is appalling to observe that the negative and restrictive gender stereotypes in the Igbo society against women has tilted in favour of male entrepreneurs' dominance, or, at the very least, that men entrepreneurs' barriers to entry to markets compared to women is more relaxed. In consequence, social norms place men and women on a relatively unequal basis in the participating in entrepreneurship. Concisely, with the practice patriarchy, expecting equivalent opportunities to both genders in entrepreneurship will always remain a mirage. By implication, cultural norms have hindered the pace at which women embrace the entrepreneurial spirit. This, James Foreman-Peck \& Peng Zhou (2014) posit, is influenced by social perceptions and cultural values: for instance, such perceptions may establish that individuals belonging to certain social groups are more apt to engage in entrepreneurial activity successfully than others. In this context, society plays a particularly important role in the entrepreneurial culture by establishing specific gender roles and stereotypes, such as the extent to which women are considered equal to men in their capacities to become entrepreneurs (Jamali, 2009). In essence, the traditional belief system places a limit on the entrepreneurial engagement of women, and as well as the positions and roles they must be engaged in economic activities. Patriarchy at its best!

Despite this, the impacts of social norms, women have relentlessly earned respect from their innovativeness in the entrepreneurial world, it is important to recognize their desire to bring change to the contemporary Igbo society of Enugu State. In a nutshell, the core argument to studying and promoting women's entrepreneurship, Ahl (2002) asserts, is that they are catalysts to economic development. Concurring, European Commission (2002) maintains that the number of gender-specific barriers women face in beginning own businesses is mind-blowing. However, there is hardly a society where gender stereotypes do not exist but not all aspects of the gender belief system negatively impact on the social positions occupied by women. In Nigeria, the socio-cultural system is gender discriminatory as the traditional belief about the position and role of women do not allow women to engage in serious economic activities and thus place a limit on the entrepreneurial engagement of women. For instance, women are still perceived as carrying the main responsibility for family and children in both the developed and the developing world (Moore and Buttner, 1997). Thus, women are traditionally ascribed a social function in the context of household- and family-related activities, and are less likely to be perceived as bread-earners, as opposed to men.

The negative effect of gender-based discriminatory laws is also reflected in the significantly lower levels of business starts among female entrepreneurs in comparison to their male peers. Even countries which have formally abolished such restrictions continue to pose constraints to female entrepreneurship via an informal culture of gender-based discrimination. For instance, while the Land and Village Land Act of 1999 in Tanzania provides for a de jure equal treatment of men and women with respect to property rights, the persistent use of local customary rules undermines the position of female entrepreneurs and their ability to inherit land and freely dispose of their property.

The legal constraints women face entail high costs related to starting a company and managing a business over an extended period of time; such costs are unlikely to be neutralized by the moderate profits women-owned businesses on average generate in emerging markets, especially where female entrepreneurs operate in the informal 
entrepreneurial sphere and do not have access to additional financing in order to expand their business activities. As a result, women entrepreneurs face greater costs in establishing start-ups compared to men, which leads many potential female entrepreneurs to decide against entering the business sphere due to an increased fear of failure.

\section{Breaking the glass ceiling for new prosperous Nigeria}

The concept of glass ceiling cannot be ignored. Before delving into the concept of glass ceiling, it is necessary we understand that in all Igbo patriarchal societies, decisions are made only with permission from the male head of the family and by extension, women are rarely accorded recognized as authority figures even in the workplace. What this socio-cultural attitude suggests for female entrepreneurs is simply that overcoming these various discriminatory practices will motivate them to gain autonomy/independence. Of course, this explains why women perceive entrepreneurship as a means to alleviate career constraints (Buttner and Moore, 1997). Because of this, women's expectations regarding the scope of benefits and outcomes are likely to attain through pursuing an entrepreneurial career much broader compared to men.

From the foregoing emerges the concept of "glass ceiling". This is a metaphor used to represent an invisible barrier that keeps a given group of persons, usually minorities from rising beyond a certain level in a hierarchy. Thus, the pervasive phenomenon of women going just so far and no further in their occupations and professions has come to be known as the glass ceiling.[78] According to Singh (2007), the "glass ceiling" is a concept describing an invisible barrier that blocks the access of women to the top - they can see where they want to get to, they can see their male peers going through, but cannot follow them because their heads are being bumped on a ceiling that is both hidden and impenetrable. In effect, women have the motivation, ambition, and capacity for positions of power and prestige, but invisible barriers keep them from reaching the top. In this vein, OECD asserts that countries where gender roles are strictly divided, whereby there is a clear separation between activities suitable for men and occupations appropriate for women, are likely to exhibit high levels of gender-based discrimination in the form of restricting women's access to certain activities, for example, the pursuit of a career in the context of entrepreneurship (James Foreman-Peck, Peng Zhou, 2014)

Writing earlier, Karen Fulbright's (1987) interviews with twenty-five AfricanAmerican women managers found fifteen who had reached the level of vice president, department head, or division director in oil, automobile manufacturing, telecommunications, and banking, or had moved rapidly up the hierarchy. The factors in their upward mobility were long tenure, a rapidly growing company, or a Blackowned or operated company. The others had experienced blocked mobility, despite positioning themselves on career tracks that were known to be the routes to the top.

In this light, breaking the glass ceiling, managing their career themselves as well as seeing themselves as legitimate potential leaders, regardless of gender, have been lubricating oil that seems to push them up. Understanding their peculiar situation as people being discriminated upon is essential, and it has provided the framework within which their entrepreneurship has blossomed beyond their imagination in a patriarchal Nigerian society.

\section{Results}

Table 1 shows that most respondents consist of 210 (75\%) females and 70 (25\%) males, mostly within the 30-39 age range with others spread across the other age sets. Most respondents are university graduates $120(42.85 \%)$ but some $50(17.85 \%)$ posses postgraduate/masters degrees. In related development, respondents' views are sought on gender and gender roles. Most respondents could not really tell what gender meant and 
simply avoided the question. Those who however, attempted to answer the question displayed a high level of ignorance.

Table 1. Bio data of respondents.

\begin{tabular}{|l|l|c|c|}
\hline \multicolumn{2}{|l|}{ Variable } & Frequency & Percentage (\%) \\
\hline \multirow{4}{*}{ Age } & $<20$ years & ------- & ----- \\
\cline { 2 - 4 } & $20-29$ years & 50 & 17.86 \\
\cline { 2 - 4 } & $30-39$ years & 130 & 46.43 \\
\cline { 2 - 4 } & $40-49$ years & 65 & 23.21 \\
\cline { 2 - 4 } & $50-$ above & 35 & 12.5 \\
\hline \multirow{2}{*}{ Total } & Total & $\mathbf{2 8 0}$ & $\mathbf{1 0 0}$ \\
\hline \multirow{2}{*}{ Educationder } & Male & 70 & 25 \\
\hline & Female & 210 & 75 \\
\hline & Total & $\mathbf{2 8 0}$ & $\mathbf{1 0 0}$ \\
\hline & SSSC & 70 & 14.3 \\
\hline & ND/NCE/ Certificate courses & 70 & 25 \\
\hline & B.Sc/ HND & 120 & 42.85 \\
\hline & Postgraduate, Masters & - & 17.85 \\
\hline & PhD & $\mathbf{2 8 0}$ & 00 \\
\hline & Total & & $\mathbf{1 0 0}$ \\
\hline
\end{tabular}

Table 2 reveals that 120 respondents (48.21\%) believe that men are responsible for leadership positions but 145 respondents indicated women as playing the provider role. That fewer men identified with the provider role is an acknowledgment that the increasing visibility of women as breadwinners in society. Women still held on to the traditional role of supporting the males and taking care of the home. It does appear from the statistics obtained that more women dominated men in bringing up children and taking care of the home therefore emphasizing women's domestic roles.

Table 2. Respondents' views on gender roles.

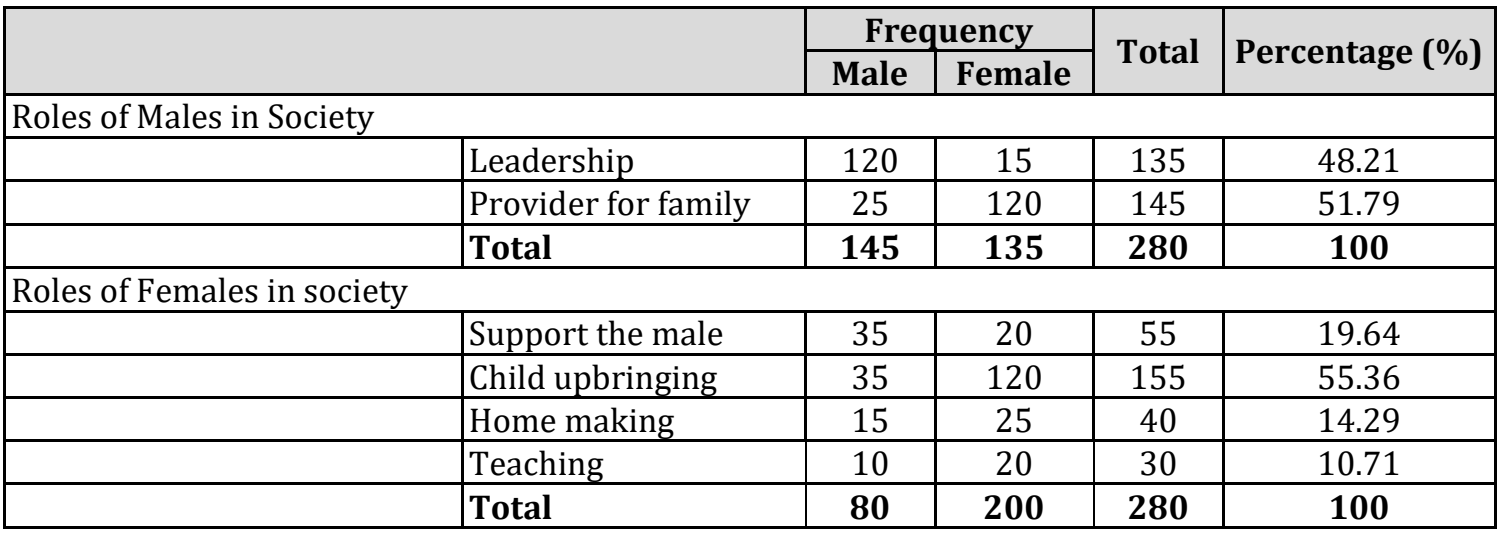

Respondents were asked if they are aware of gender education, majority 248 $(88.57 \%)$ said they had heard about it, while 32 respondents $(11.43 \%)$ of the respondents had never. Asked if both males and females have equal access to education, 198 (70.71\%) of the respondents affirmed that both genders have equal opportunity to education but 82 (29.29\%) did not share this view. Having same kind of education for both genders, 90 
(32.29\%) agreed; in ensuring both males and females understand the boundaries, 25respondents (8.93\%) support it, while teaching them differently, only 5 respondents $(1.79 \%)$ are in concord with this perspective. 160 respondents $(57.14 \%)$ submit that acquiring education enhances gender sensitivity. But when asked specifically about gender education, 130 (46.43\%) of the respondents admitted they know. Unfortunately, those who claimed to know associated gender education with sex education. Similarly, 110 (39.29\%) agree that gender mainstreaming is all about bringing together of different genders to share ideas, while $30(10.71 \%)$ said it is about mixed schools.

Furthermore, respondents were asked if they had received any gender training, the vast majority $260(92.86 \%)$ admitted they had received, but 20(7.41\%) however, said they had not. For those who had received, 75 respondents $(26.79 \%)$ got it through short courses while 60 respondents (21.43\%) had it through seminars. In addition, 40 respondents $(14.28 \%)$ were through enrolling in diploma programmes, while70 respondents $(25 \%)$ had by obtaining degree programmes.

Table 3 clearly indicates that a good number of respondents seem to understand the impacts of gender education on female entrepreneurship. Respondents were asked if they were aware of the impacts of gender education and the majority 248 (88.57\%). said they had heard about it, while 32 respondents (11.43\%) of the respondents had never heard of it. Asked if both males and females have equal access to education, 198 (70.71\%) of the respondents affirmed that both genders have equal opportunity to education but 82 (29.29\%) did not share this view. Having same kind of education for both genders, 90 (32.29\%) agreed; in ensuring both males and females understand the boundaries, 25respondents (8.93\%) support it, while teaching them differently, only five respondents $(1.79 \%)$ are in concord with this perspective and finally, 160 respondents $(57.14 \%)$ submit to acquiring education that enhances gender sensitivity. But when asked specifically about gender education, majority admitted they know as indicated by 130 $(46.43 \%)$ of the respondents. Those who claimed to know associated gender education with sex education. Similarly, 110 (39.29\%) agree that gender mainstreaming means bringing together of different genders to share ideas, while $30(10.71 \%)$ said it is about mixed schools.

This assertiveness was put to the test when respondents were further asked to indicate the highest educational attainment males and females should aspire to gain.

Table 4 shows that respondents were of the view that the aspiration of males to higher is inconsequential since the social norms are always in their favour. Buttressing this assertion, we observed that for tertiary education and secondary school, male enrollments indicate $46.44 \%$ and $35.71 \%$ respectively, while for females, $25 \%$ and $51.79 \%$ were recorded. By implication, for secondary school, the statistics for males was higher $(46.44 \%)$ while female had $25 \%$. But the reverse was the case in tertiary where females had $51.79 \%$ while males gained $35.71 \%$. The only plausible explanation is that women, viewed from the various degrees of discrimination, marginalization and exclusion have seen tertiary education as pre-requisites for breaking the glass ceilings for a new prosperous Nigeria. This is further strengthened by the fact that males recorded only $30(10.71 \%)$ respondents were in support of post graduate programmes for males, but no single respondent was in agreement with males aspiring up to doctorate levels. On the contrary, 47 respondents $(16.78 \%)$ agreed with females going for post graduate certificates, and 3 respondents representing $1.07 \%$ supporting doctorate programmes 
Table 3. Respondents' understanding of Gender education and Female entrepreneurship.

\begin{tabular}{|c|c|c|c|}
\hline \multicolumn{2}{|l|}{ Variables } & Frequency & Percentage (\%) \\
\hline \multirow{3}{*}{$\begin{array}{l}\text { Awareness of the impacts of Gender } \\
\text { education }\end{array}$} & Yes & 248 & 88.57 \\
\hline & No & 32 & 11.43 \\
\hline & Total & 280 & 100 \\
\hline \multirow{3}{*}{$\begin{array}{l}\text { Access to equal educational } \\
\text { opportunities for males and females }\end{array}$} & Yes & 198 & 70.71 \\
\hline & No & 82 & 29.29 \\
\hline & Total & 280 & 100 \\
\hline \multirow[t]{5}{*}{ Understanding of Gender Education } & $\begin{array}{l}\text { Education for both } \\
\text { genders }\end{array}$ & 90 & 32.14 \\
\hline & $\begin{array}{l}\text { System for Males and } \\
\text { Females to understand } \\
\text { boundaries }\end{array}$ & 25 & 08.93 \\
\hline & $\begin{array}{l}\text { Education to enhance } \\
\text { gender sensitivity }\end{array}$ & 160 & 57.14 \\
\hline & $\begin{array}{l}\text { Teaching males and } \\
\text { females differently }\end{array}$ & 5 & 01.79 \\
\hline & Total & 280 & 100 \\
\hline \multirow{3}{*}{$\begin{array}{l}\text { Do we need female } \\
\text { entrepreneurship? }\end{array}$} & Yes & 260 & 92.86 \\
\hline & No & 20 & 7.14 \\
\hline & Total & 280 & 100 \\
\hline \multirow[t]{6}{*}{ If yes, how should they be trained } & Short course & 75 & 26.79 \\
\hline & Training workshop & 35 & 12.50 \\
\hline & Seminar & 60 & 21.43 \\
\hline & Diploma & 40 & 14.28 \\
\hline & Degree & 70 & 25 \\
\hline & Total & 280 & 100 \\
\hline \multirow[t]{5}{*}{$\begin{array}{l}\text { Understanding of Gender } \\
\text { Mainstreaming }\end{array}$} & $\begin{array}{l}\text { Activities of females that } \\
\text { contrasts male }\end{array}$ & 10 & 3.57 \\
\hline & $\begin{array}{l}\text { Approach that values } \\
\text { education for all genders }\end{array}$ & 130 & 46.43 \\
\hline & $\begin{array}{l}\text { Bringing together of } \\
\text { different genders to } \\
\text { share ideas }\end{array}$ & 110 & 39.29 \\
\hline & Mixed schools & 30 & 10.71 \\
\hline & Total & 280 & 100 \\
\hline
\end{tabular}

Table 4. Respondents views on level of educational attainment for each gender.

\begin{tabular}{|l|l|c|c|}
\hline Variables & & Frequency & Percentage (\%) \\
\hline \multirow{4}{*}{$\begin{array}{l}\text { Highest level of Education males should to pursue } \\
\text { aspire }\end{array}$} & Primary School & 20 & 7.14 \\
\cline { 2 - 4 } & Secondary school & 130 & 46.44 \\
\cline { 2 - 4 } & Tertiary & 100 & 35.71 \\
\cline { 2 - 4 } & Post graduate (masters) & 30 & 10.71 \\
\cline { 2 - 4 } & Post graduate (PhD) & ---- & ------ \\
\cline { 2 - 4 } & Total & $\mathbf{2 8 0}$ & $\mathbf{1 0 0}$ \\
\hline \multirow{3}{*}{$\begin{array}{l}\text { Highest level of education females } \\
\text { entrepreneurs should aspire to pursue }\end{array}$} & Primary School & 15 & 5.36 \\
\cline { 2 - 4 } & Secondary school & 70 & 25 \\
\cline { 2 - 4 } & Tertiary & 145 & 51.79 \\
\cline { 2 - 4 } & Post graduate (masters) & 47 & 16.78 \\
\cline { 2 - 4 } & Post graduate (PhD) & 3 & 1.07 \\
\cline { 2 - 4 } & Total & $\mathbf{2 8 0}$ & $\mathbf{1 0 0}$ \\
\hline
\end{tabular}




\section{Discussion}

From the first research question, it was observed that there is an affirmative concord between the impact of gender education and female entrepreneurs in Nigeria, particularly in Enugu State. From the data obtained, Mayoux (2001) observes that there are certain factors that limit female entrepreneurs' ability to take advantage of the opportunities available to excel and some of these factors include lack of gender education, social norms and inability to access free credit facilities from financial institutions. Consequent upon this, the study submit that acquiring gender education headlong with emphasis on vocational education will boost the success of female entrepreneurship. Aside this, the pervasive phenomenon of women going just so far and no further in their quest to be economically independent, known as glass ceiling would be shattered by acquiring appropriate learning and training. Succinctly, gender education will promote women's entry into entrepreneurship, and increase their acquisition and possession of cognitive skills. The possession of cognitive skills makes success of women's entry into entrepreneurship. Thus, we conclude that education is a pathway to gender equality in Nigeria's entrepreneurship because it reduces gender gaps in earnings. Besides, since women are of immense significance, their huge impact in the sustenance of the Nigeria's economy cannot be ignored (Ayogu and Agu, 2015). To this effect, female entrepreneurs are important and necessary for the socio-economic transformation of Nigeria.

Data gathered from the second research question showed that social norms have hindered female entrepreneurs from improving their economic status. As Nigeria is a highly patriarchal society where men dominate all spheres of women's lives, it is worrisome to concede that the discrimination and subjugation is purposely to silence and scheme them out of their inner most desire to be economical independent through engaging in entrepreneurship. Apparently, the social relations and activities of Nigerian women and men are governed by patriarchal systems of socialization and cultural practices which enabled the interests of men above those of women. Following this, social norms regarding gender and gender roles have become decisive factors within the culture of female entrepreneurship. Upholding this strand of thought, are numerous researches which reveal that socio-cultural practices have not only continued to halt socio-economic activities of female entrepreneurs to the collective detriment of the Nigerian society, but also gender equality.

Explicitly, the impediments arising from this gender-based division of socially acceptable functions for female entrepreneurs has in no small way hindered them from excelling. While we may hold that gender-based discrimination is obvious, but much less perceivable in the present day society, the vexing questions are: why are majority of the female entrepreneurs still crawling in the entrepreneurial world? Secondly, why have they become so vulnerable to social norms? Is it that gender belief system still view women as having lower propensities to engage in entrepreneurship than men? In attempting to answer these questions, respondents submit that gender education should be appreciated as it gives female entrepreneurs self confidence to exercise control in matters of interest in any entrepreneurial setting. In other words, education that stagnate women, chide and control the instruments of patriarchy is never an option.

Strangely, even when female entrepreneurs have opportunity to earn high income, they are subjected, by virtue of culture and tradition, under their husbands who not only control them, but have access to their funds. Limiting female entrepreneurs in participating fully in private enterprises is the aftermath of their discrimination and oppression. In as much as recent studies in Nigeria indicate that one effect of this differential is cultural-living in a patriarchal society where women are conditioned to feel out of place in this sphere of influence. The stereotyping and the unfortunate exposure 
of women to the realities of contemporary times has been an obstacle to their overall development, particularly in the entrepreneurial world.

\section{Conclusion}

The findings of this study show that gender education has aided female entrepreneurs to break the glass ceiling and contributes to transform the patriarchal Igbo society, especially Enugu state. Evidently, gender education is the most viable and veritable vehicle for guaranteeing and sustaining female entrepreneurs to continue to expand entrepreneurship in Nigeria. Basically, the contributions of female entrepreneurs in Nigeria's entrepreneurship development cannot be underestimated because their contributions have been remarkable despite the challenges they face. Nevertheless, this study has presented a different picture of women making some tremendous efforts in spite of all odds to excel in promoting the necessity of gender education on female entrepreneurship.

Based on the findings, the following recommendations are hereby provided:

1. Since female entrepreneurs have been described as catalysts to transforming the Nigerian society, the socio-economic development of Enugu state should be a priority to spur them into more commitments in entrepreneurship so as to gain self- confidence and self-esteem which are important factors in taking the risks - the core of entrepreneurship..

2. Since social norms have been identified as stumbling blocks to the blossoming of female entrepreneurship, government should the legislative arm, enact laws to cancel all social cultural practices against women in conformity with article 5.5.2 that emphasizes the need to eliminate those aspects of our culture that inhibit the development of positive of selfidentity of women and their full participation in society.

3. Besides, one of the reasons for women's oppressions for several decades is the fact that it was grounded on their economic position since they were relegated to inferior and dependent positions, there should be programmes to assist women entrepreneurs to reinvent their self esteem and plunged into them back into entrepreneurship headlong.

4. Above all, there should be interest free loans and other financial incentives to assist and encourage women entrepreneurs and also involved in societal encouragement of women's involvement in innovation and productivity.

\section{Conflict of interests}

Authors declare that they have no conflict of interests.

\section{References}

Ahl, H. J. The making of the female entrepreneur: A discourse analysis of research texts on women's entrepreneurship. Jönköping: Jönköping University, 2002. (JIBS Dissertation Series, 15).

Ayogu, D. U.; Agu, E. O. Assessment of the contribution of women entrepreneur towards entrepreneurship development in Nigeria. International Journal of Current Research and Academic Review, v. 3, no. 10, p. 190-207, 2015.

Baden, H. R. Gender and development: Concepts and definitions. Brighton: Bridge, 2000. 
Bonvillain, N. Cultural Anthropology. Boston, MA: Pearson Education, 2006. (Custom Edition for Houston Community College System).

Eisenstein, Z. Constructing a theory of capitalist patriarchy and socialist feminism. Critical Sociology, v. $25, \quad$ no. $2 / 3, \quad$ p. $196-219$, 1999. https://doi.org/10.1177/ 08969205990250020901

Ejumodo, K. B. O. Gender equality and women empowerment in Nigeria: The desirability and inevitability of a pragmatic approach. Developing Country Study, v. 3, no. 4, p. 59-66, 2013.

European Commission. Entrepreneurship in the EU and beyond. Flash Eurobarometer, no 354, 2012. Available from: <http://ec.europa.eu/public_opinion/flash/fl_354_en.pdf>. Accessed on: Mar. 23, 2019.

Funmilola, A. 'Dr' Girl-Child Education: A reality or a mirage among females with hearing impairment in Nigeria. The International Journal of the Humanities, v. 5, no. 3, p. 87-92, 2007. https://doi.org/10.18848/1447-9508/CGP/v05i03/42028

Global Entrepreneurship Research Association. The 2015/2016 Global Entrepreneurship Monitor. London: Global Entrepreneurship Research Association, 2017.

Jalilian, P. The effects of female education on human development and economic growth: A study of human capital formation in developing countries. Sodestorn: Sodestorn University, 2012. (Master thesis).

Jamali, D. Constraints and opportunities facing women entrepreneurs in developing countries: A relational perspective. Gender in Management, v. 24, no. 4, p. 232-251, 2009. https://doi.org/10.1108/17542410910961532

Kaur, N. G.; Letic, J. Female education and economic growth: Theoretical overview and two country cases. Gothenburg: University of Gothenburg, 2012 (Bachelor thesis).

Kroeber, A. The subject of Anthropology. In: Fried, M. H. H. (Ed.). Readings in Anthropology. New York: Thomas Y. Crowell Company, 1968. p. 3-5.

Moore, D. P. An examination of present research on the female entrepreneur: Suggested research strategies for the 1990's. Journal of Business Ethics, v. 9, p. 275-281, 1990. https://doi.org/10.1007/BF00380327

Moore, D. P.; Buttner, E. H. Women entrepreneurs: Moving beyond the glass ceiling. Thousand Oaks, CA: Sage Publications, 1997.

Niethammer, C. Women entrepreneurship and the opportunity to promote development \& business. In: Brookings Institute. Enterprising solutions: The role of the private sector in eradicating global poverty. Policy brief, Sept., 2013. p.31-39. Available from: <http://www.brookings.edu/ /media/research/files/reports/2013/09/private-sectorglobal-poverty-blum-roundtable/2013-bbr-women-entrepreneurship.pdf $>$. Accessed on: Mar. 23, 2019.

OECD - Organization for Economic Cooperation and Development. Closing the gender gap: Act now, 2012. Available from: <http://www.oecd.org/gender/closingthegap.htm>. Accessed on: Mar. 23, 2019.

Omadjohwoefe, O. S. Gender role differentiation and social mobility of women in Nigeria. $\begin{array}{lllll}\text { Journal of Social Sciences, } & \text { v. 27, } & \text { no. 1, } & \text { p. 67-74, } 211 .\end{array}$ https://doi.org/10.1080/09718923.2011.11892907 
Schumpeter, J. The theory of economic development. Cambridge: Harvard University, 1934.

Ugrinova, R. R. Female education and entrepreneurship as drivers of economic development: How the right to education can enhance female entrepreneurship and contribute to economic growth. Tilburg: Tilburg University, 2016. (Master thesis).

Witt, S. Parental influence on children's socialization in gender roles. Adolescence, v. 32, no. 126, p. 253-259, 1997.

Woetzel, J.; Madgavkar, A.; Ellingrud, K.; Labaye, E.; Devillard, S.; Kutcher, E.; Manyika, J.; Dobbs, R.; Krishnan, M. The power of parity: How advancing women's equality can add \$12 trillion to global growth. Washington, DC: McKinsey \& Co, 2015.

World Bank. Female entrepreneurship: Program guidelines and case studies. World Bank, 2015. Available from: <http://siteresources.worldbank.org/EXTGENDER/Resources/ FemaleEntrepreneurshipResourcePoint041113.pdf>. Accessed on: Mar. 21, 2019.

World Bank. Measuring the economic gains of investing in girls: The girl effect dividend. World Bank, 2011. (Policy research working paper). 